\title{
The Utilization of Mobile Learning "Be One" in the Pancasila and Civics Subject
}

\section{(A Case Study of Grade 8 Students at Baleendah 1 Junior High School)}

\author{
Risna Lestari ${ }^{1, *}$, Muhammad Halimi ${ }^{2}$ \\ ${ }^{1,2}$ Universitas Pendidikan Indonesia \\ *Corresponding Authors. Email: risnalestari@upi.edu
}

\begin{abstract}
The spread of the COVID-19 virus has a direct impact on various LIFE aspects, one of which is the education sector. The efforts to prevent the COVID-19 virus in educational settings are performed through online learning activities from home. The development of information and communication technology encourages the use of electronic devices as learning media. E-Learning in the form of applications on mobile phones through the internet technology allows teaching and learning activities to be carried out via mobile or m-Learning. The use of m-learning as a medium to support the learning process creates convenience in the teaching and learning process. The $\mathrm{m}$-learning program in this study was a learning application called "be-ONE" used as a mobile-based learning media to facilitate the learning activities in the pandemic era at Bale Endah 1 Junior High School. This study was conducted using a qualitative method with a case study approach to investigate the use of the mobile learning application "BE ONE" with 5 feature options in the application, including attendance list, e-library, e-learning, e-meeting, and broadcasting. The analysis results showed that the m-learning feature with the highest use and effectiveness was the e-learning menu. Overall, the "BE ONE" application was used optimally by both teachers and students in the teaching and learning process at Bale Endah 1 Junior High School.
\end{abstract}

Keywords: Civic Subject, Mobile Learning, Pancasila.

\section{INTRODUCTION}

The massive spread of the coronavirus in Indonesia has prompted the Ministry of Education and Culture (Kemendikbud) to take measures to prevent its spread in schools by instructing students to do online learning activities. The learning-from-home activities are assisted by various media such as electronic devices such as cell phones or laptops which are supported by the internet network. Online learning is a solution so that education can keep going during a pandemic. Learning by utilizing an online platform to support the implementation of distance learning is an inevitable need. The use of mobile phones in e-learning offers convenience for teachers and students to be able to learn and teach anywhere and anytime with a high level of flexibility, where teachers and students no longer need computers to access e-learning. ELearning which is performed through mobile applications with the assistance of the internet allows teaching and learning activities to be done on the smart phones. M-
Learning is a combination of E-Learning and Mobile Computing[5].

The use of mobile learning is more effective and efficient than the use of computers. Mobile learning is a new trend in the learning process because of its ease of use where students can use it whenever and wherever they are. The m-learning program in this study is a learning application called "be-ONE" as a mobile-based learning media. The "be-ONE" application is a learning media provided by schools to facilitate learning activities in the era of the pandemic at Bale Endah 1 Junior High School. The "BE ONE" application which is used as a learning medium at Baleendah 1 Junior High School is used by teachers and students in learning activities. The menus include the attendance list, e-library, elearning, e-meeting, and broadcasting. The attendance list menu is used to monitor the attendance of teachers and students in every online meeting. The e-library menu is an online library portal provided by Baleendah 1 Junior High School which can be used by both teachers and students to get reading 
sources related to subjects taught at school and general knowledge. The e-learning menu is used for teachers and students to access online meetings, download learning materials, access discussion forums, and take quizzes and exams. E-meeting can be used by teachers and students to conduct online meetings either through Google Meet, Zoom Meeting, Cisco Webex, or Microsoft Team. The broadcasting menu facilitates teachers and students to access information related to school activities through digital media such as Instagram, YouTube, telegram, BEONE TV, BEONE Radio, and WhatsApp.

Pancasila and Civics Education is a school subject with the target of providing the students with noble characters, guidance on beliefs, ethical rules, and norms that must be obeyed by every citizen. Pancasila and Civics Education aims to make students have a love for the country and a spirit of nationality as part of the moral values of Pancasila. The purpose of the subject learning for secondary school education is to develop students' abilities in citizenship aspects such as an attitude of independence and a sense of responsibility and confidence as Indonesian citizens, literacy, and civics knowledge and to improve students' abilities in civics participation. Therefore, the current study was conducted to identify the use of mobile learning "Be One" at Pancasila and Civics Subject for Grade 8 Students at Bale Endah 1 Junior High School.

\section{THEORETICAL REVIEW}

\subsection{Mobile Learning}

[1] Stated that e-learning is a new learning method and system by utilizing previously developed technology which is then implemented and collaborated in the education sector to improve the quality of learning and teaching by realizing teaching material in digital form. Mobile learning is an electronic educational media or learning process that uses cellular technology which is commonly called a cell phone (smartphone).The development of this mobile device continues to increase every year and is much easier to operate than a computer. Mobile devices are an alternative solution for creating learning media applications. With mobile learning, students can easily use and take advantage of these technological advances by learning flexibly when they need it without having to come to school at a certain time. [3] Defines mobile learning as a part of cellular computing and electronic learning where resources can be accessed anywhere with dense search capabilities, diverse interactions, learning convenience, and performance evaluation. Explains that mobile learning is a type of learning that does not require teachers and students to be in certain locations. [4] Mobile learning is a teaching and learning activity that can use cellular equipment, for example, PDAs, cell phones, and laptops.

Mobile learning has the advantage of providing learning materials that can be used at any time by visualizing the material in a digital format. The term "mobile learning" is also used for handheld mobile devices used in teaching and learning processes such as cell phones, laptops, and media-focused information technology devices. The development of mobile learning has always been the main goal in the learning process. All the conveniences in the learning process can make the students more enthusiastic and can streamline time while operating applications for the learning process. The students do not need to go to class to collect homework. They just need a mobile app that can send the homework.

Mobile learning is a medium for understanding the learning material so that it can allow the learning process to be performed without face to face and can be done anywhere as long as it has an internet connection. The advantage is that this mobile learning method can be used appropriately according to the target and can improve the quality of student learning in the future. Mobile learning in the current study is the design of digital learning media based on cellphone hardware or mobile phones which is developed in an application and is equipped with several features including E-Library, E-Learning, E-Meeting, and Broadcasting. In the field of education, the development of digitalization technology is in the form of the learning media development program in the 4.0 era, i.e. digitalization-based learning using electronic devices and digital media. Mobile learning can educate students that learning can be done easily by using their electronic communication devices.

\subsection{Maintaining the Integrity of the Specifications Pancasila and Civics Subject}

Pancasila and Civics Education refers to the name of an official subject in schools taught to students so that they become people who have a sense of belonging and love for their homeland. This objective is characterized by the implementation of the 1945 Constitution, the values of the basic principles of Pancasila, the spirit of diversity, and the growing sense of responsibility to the Republic of Indonesia in social life. This statement is contained in Government Regulation No. 32 of 2013 related to the national criteria for learning, the description of Article $77 \mathrm{~J}$ paragraph (1). This subject is taught to the students of primary, junior high, and senior high students. It aims to increase the students' citizenship skills and knowledge as stated in the 6 principles of civics behavior, namely:
a. Civics Confidence
b. Civics Commitment
c. Civics Responsibility
d. Civics Knowledge
e. Civics Competence
f. Civics Participation

The Pancasila and Civics Subject was originally known as Civics Education. Along with the accumulation of sentences and the meanings listed therein, currently, the subject has the following scopes:

a. Pancasila as the nation's view of life, the nation's principle, and the nation's model of thinking. 
b. The 1945 Constitution of the Republic of Indonesia as the legal basis in the form of a manuscript as a basic reference for the life of the nation.

c. The term NKRI (The Unitary State of the Republic of Indonesia) is a form of agreement on the structure of the Indonesian State.

d. Bhinneka Tunggal Ika as the essence of the unity of Indonesia which consists of various ethnic groups and cultures.

\subsection{Pancasila and Civics Subject for grade 8 students}

The 2013 curriculum is based on the direction of the Minister of Education and Culture (hereinafter abbreviated to the Minister of Education and Culture) volume 24 of 2016 regarding Core Competencies and Basic Competencies for the junior high school that formulates the scopes of the subject modules as follows:

a. Pancasila as the national foundation and the thinking of the life of the Indonesian nation

b. The meaning, position, and role of the 1945 Constitution in the life of Indonesian society

c. Design of statutory provisions in the Indonesian legal system

d. The wisdom and value of the 1908 National Awakening

e. Morals and passion of the 1928 Youth Pledge

f. Enthusiasm and commitment to the nation

\section{METHOD}

The present study employed a qualitative method with a case study approach. [2] Argues that qualitative means when the researcher tries to understand the conditions experienced by the research subjects/participants. Meanwhile, a case study means the process of an in-depth and comprehensive study of a person, group, social situation, or organization and is determined within a certain time limit [6]. The topic to be discussed in this study: how was the use of the "BE ONE" mobile learning application at Bale Endah 1 Junior High School through 5 assessment indicators/menu, including attendance list, elibrary, e-learning, e-meeting, and broadcasting. The participants in this study were all teachers who taught Pancasila and Civics Subject for the grade 8 students at Bale Endah 1 Junior High School and representatives from each class of the grade 8 students at Bale Endah 1 Junior High School. [6] Explains that data collection techniques for a case study research include documents, voice recording, interviews, observations, and physical devices. This study applied a systematic observation technique in the form of online learning observations using the mobile learning application "be-ONE" belonging to Bale Endah 1 Junior High School. The study also used structured interviews which gave several questions to students, teachers, school management, and parents as research participants.

\section{RESULT AND DISCUSSION}

The be-ONE application is an android based application with a Web to Apps system or the integration of any website into an app. School websites and e-learning websites are integrated into an application that can be accessed via an Android-based smartphone. This application has been shared on the google play store so it can be accessed and downloaded for free. The be-ONE application has several menus including the attendance list, e-library, e-learning, e-meeting, and broadcasting.

Through the be-ONE application, all members of Baleendah 1 Junior High School can access information about schools, libraries, broadcast (radio and TV), and fill in the daily attendance list online. Especially for teachers and students, they can also access various distance learning content and online assessments such as daily assessments, midterm assessments, end-of-semester assessments, year-end assessments, and school exams. The be-ONE application is managed by the Vice Principal for Facilities and Infrastructure assisted by the school's IT Team. On several occasions, it has also been assisted by a third party who is competent in developing smartphone applications, namely a team that provides content creation for smartphones called Androjex.

The be-ONE application is designed as a one-stop application that aims to integrate access to the main school website, school library website, school distance learning, or e-learning system website (Moodle) and third parties (such as teacher rooms, learning houses, quizzes, goggles classroom, Edmodo, etc.), websites or links to virtual meeting applications (such as zoom, google meet, WebEx, and Microsoft teams), school broadcasting websites, and filling in the daily attendance list of teachers, school staffs, and students. With this integration, the students can easily access various systems through one app. It is hoped that the ease of access to these various systems can accelerate distance learning activities and reduce internet quota consumption.

\section{The Utilization of be-One Mobile Learning by Teachers} and Students

The interviews conducted with 5 Pancasila and Civics Education teachers and 40 grade 8 students at Bale Endah 1 Junior High School show the students' responses to the use of the be-ONE application through the attendance list, e-library, e-learning, e-meeting, and broadcasting menus. The "be-One" menus are described below.

\section{1) Attendance List}

The attendance list feature is a menu to record the attendance of teachers and students. Based on the results of interviews with students, the attendance list menu is sometimes difficult to access, so they must confirm their attendance in the Pancasila and Civics Education class by contacting the homeroom teacher to fill in the attendance list. This makes the student's attendance in class 'not recorded'. 


\section{2) E-library}

The e-library feature is used by both teachers and students to get reading sources related to Pancasila and Civics Education and other subjects taught in schools. The students will be notified if the reading material in this feature is limited. Nevertheless, so far through the elibrary feature, the students can access reading materials easily.

\section{3) E-learning}

The e-learning menu is used by teachers and students to access Pancasila and Civics online meetings which are conducted, download materials or teaching materials, discussion forums, and take exams and quizzes. The students can follow the subject well through e-learning, although sometimes the limitations of online learning make it difficult for students to ask further questions about the lessons being taught and teachers face limitations in explaining the lessons in more detail.

\section{4) E-meeting}

The e-meeting menu can be used by teachers and students to conduct online meetings either through Google Meet, Zoom Meeting, Cisco WebEx, or Microsoft Team. However, the students and teachers mostly use zoom meetings because it is considered easier to use even when the internet connection is low. In proving services to students at Baleendah 1 Junior High School, the school provides paid zoom services so the online learning activities run smoothly, including for Pancasila and Civics Education subject meetings. The use of the e-meeting menu on the be-ONE application is considered very effective for students. This is because the students can interact directly with teachers and classmates and receive learning materials directly.

\section{5) Broadcasting}

The broadcasting menu facilitates teachers and students to access information related to school activities through digital media such as Instagram, YouTube, telegram, BEONE TV, BEONE Radio, and WhatsApp. The broadcasting menu is very effective in disseminating information to students. Here are some uses of broadcasting in distance learning:

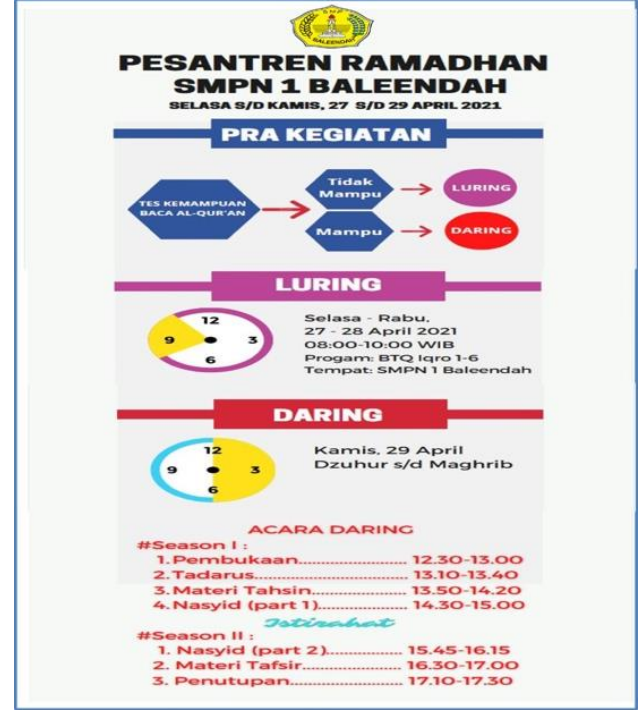

Figure 1. The implementation of the Islamic boarding school for Ramadhan is broadcasted live on be-ONE tv since it can be performed offline and online (hybrid).

\section{CONCLUSION}

1) The be-ONE application helps teachers in conducting classroom teaching activities because the learning features contained in it are complete to support teachers in the learning activities. However, the teachers still face limited interaction with their students so the teachers can only provide teaching material without practice. This is an obstacle since one of the objectives of Pancasila and Civics Education subject is the formation of student character. Overall, for Pancasila and Civics subject, the students made good use of m-learning be-ONE. The students' motivation and enthusiasm for learning the subject increases with the support of the be-ONE application since they can learn it using smartphones anytime and anywhere. The limitations experienced by students are related to technical matters such as poor internet networks so that they have difficulty accessing features in the be-One application. In addition, the limited interaction with the teachers makes it difficult for students to have further discussions about the materials in the Pancasila and Civics subject.

2) Student participation in Pancasila and Civics Education learning activities through the be-ONE application is in the range of $90 \%$. A small proportion of students have not been able to take part in learning due to their economic limitations. Therefore, the school prepares LKPD (Student Worksheet) so the students can still study at home. The be-ONE application is effective in helping students to learn and understand the Pancasila and Civics subject. The subject's scopes including Pancasila as the national foundation and the thinking of the life of the Indonesian nation, the meaning, position, and role of the 1945 Constitution in the life of Indonesian society, design of statutory provisions in the Indonesian legal 
system, the wisdom and value of the 1908 National Awakening, morals and passion of the 1928 Youth Pledge, and enthusiasm and commitment to the nation are conveyed through various features in the be-One application such as e-learning menu in delivering materials and e-meeting menu which serve as a forum for teachers and students to interact virtually. However, due to the pandemic condition, two chapters were not fully presented in this Pancasila and Civics subject, namely Interpreting Legislation and Strengthening National Commitment. The assessments made to students in online learning are of course different from face-to-face learning. In his case, the teachers cannot assess and observe student attitudes so the assessments are only given based on academic scores. The grade 8 students' scores on Pancasila and Civics subject conducted online with mobile learning be-One can be considered 'good' and has no difference with those when the subject is conducted face-to-face.

3) The be-ONE application is effective in helping students to learn and understand the Pancasila and Civics subject. It is hoped that the be-ONE mobile learning can be developed into a multiplatform application (android and iOS) and a database app. With this development, it is hoped that it can integrate more educational content and games. This application is also expected to be developed and used to display real-time data on the involvement of students and teachers in learning activities, both learning material, attendance, and grades, which can be accessed by the parents of students. With continuous development, be-One mobile learning is expected to help Bale Endah 1 Junior High School achieve its status as a digital school that facilitates access for teachers and students in multiplatform learning activities that are fun, reliable, and accountable.

\section{REFERENCES}

[1] Adicondro, N. \& Purnamasari, Alfi. Efikasi Diri, Dukungan Sosial Keluarga dan Self Regulated Learning Pada Siswa Kelas VIII. Jurnal Humanitas, Vol. VIII No.1. http://dx.doi.org/10.26555/humanitas.v8i1.448. 2011

[2] Quinn, C. Mlearning, Mobile Wireless in Your Pocket

Learning.http://www.linezine.com/2.1/feature/cqm mwiyp.html. 2000.

[3] Sutopo, Ariesto H. Teknologi Informasi dan Komunikasi dalam Pendidikan.Yogyakarta: Graha Ilmu. 2012.

[4] Thohari, A. N. A., Satoto, K. I., \& Martono, K. T. Pembuatan Aplikasi Mobile Learning sebagai Sarana Pembelajaran di Lingkungan Universitas Diponegoro. Jurnal Teknologi Dan Sistem Komputer, $\quad 1(2), \quad 56$. https://doi.org/10.14710/jtsiskom.1.2.2013.56-65. 2013

[5] Yin, Robert K; Djauzi Mudzakir, M. Studi kasus: desain \& metode / Robert K. Yin ; penerjemah, M. Djauzi Mudzakir. Jakarta: Raja Grafindo Perkasa. 2008 